\title{
Article \\ Theoretical and Experimental Research of Hydrogen Solid Solution in Mg and Mg-Al System
}

\author{
Jinzhe Lyu (D), Roman R. Elman *, Leonid A. Svyatkin (D) and Viktor N. Kudiiarov (D)
}

check for updates

Citation: Lyu, J.; Elman, R.R.; Svyatkin, L.A.; Kudiiarov, V.N. Theoretical and Experimental Research of Hydrogen Solid Solution in $\mathrm{Mg}$ and $\mathrm{Mg}-\mathrm{Al}$ System. Materials 2022, 15, 1667. https://doi.org/ $10.3390 / \mathrm{ma} 15051667$

Academic Editor: Eli Grigorova

Received: 30 December 2021

Accepted: 21 February 2022

Published: 23 February 2022

Publisher's Note: MDPI stays neutral with regard to jurisdictional claims in published maps and institutional affiliations.

Copyright: (C) 2022 by the authors. Licensee MDPI, Basel, Switzerland. This article is an open access article distributed under the terms and conditions of the Creative Commons Attribution (CC BY) license (https:// creativecommons.org/licenses/by/ $4.0 /)$.
Division for Experimental Physics, School of Nuclear Science \& Engineering, National Research Tomsk Polytechnic University, Lenin Ave. 43, 634050 Tomsk, Russia; czinchzhe1@tpu.ru (J.L.); svyatkin@tpu.ru (L.A.S.); kudiyarov@tpu.ru (V.N.K.)

* Correspondence: rre1@tpu.ru; Tel.: +7-913-880-1428

\begin{abstract}
The study of hydrogen storage properties of Mg-based thin films is of interest due to their unique composition, interface, crystallinity, and high potential for use in hydrogen-storage systems. Alloying Mg with Al leads to the destabilization of the magnesium hydride reducing the heat of reaction, increases the nucleation rate, and decreases the dehydriding temperature. The purpose of our study is to reveal the role of the aluminum atom addition in hydrogen adsorption and accumulation in the $\mathrm{Mg}-\mathrm{H}$ solid solution. Ab initio calculations of aluminum and hydrogen binding energies in magnesium were carried out in the framework of density functional theory. Hydrogen distribution and accumulation in $\mathrm{Mg}$ and $\mathrm{Mg}-10 \% \mathrm{Al}$ thin films were experimentally studied by the method of glow-discharge optical emission spectroscopy and using a hydrogen analyzer, respectively. It was found that a hydrogen distribution gradient is observed in the $\mathrm{Mg}-10 \% \mathrm{Al}$ coating, with more hydrogen on the surface and less in the bulk. Moreover, the hydrogen concentration in the $\mathrm{Mg}-10 \% \mathrm{Al}$ is lower compared to $\mathrm{Mg}$. This can be explained by the lower hydrogen binding energy in the magnesium-aluminum system compared with pure magnesium.
\end{abstract}

Keywords: magnesium; aluminum; thin film; hydrogen; first-principle calculations

\section{Introduction}

As a high-energy-density and clean energy source, hydrogen energy has attracted increasing attention. The development and utilization of hydrogen energy involve the preparation, storage, transportation, and application of hydrogen. The storage of hydrogen energy is the key to expand the usage of hydrogen energy [1-6]. Among the numerous hydrogen storage materials [7-10], $\mathrm{Mg}$ is one of the most promising candidates due to its high hydrogen storage capacity up to $7.6 \mathrm{wt} \%$, light weight, and low cost [11]. However, the main obstacle preventing the commercial use of magnesium as a hydrogen storage material is the low diffusion rate of hydrogen atoms in $\mathrm{MgH}_{2}$ layers [12,13]. Additionally, the activation energy of $\mathrm{MgH}_{2}$ formation can be overcome only at a high temperature up to $300{ }^{\circ} \mathrm{C}$ [11]. Tremendous efforts have been devoted to decreasing the diffusion barrier and hydrogenation temperature rate, including doping catalysts [14-20] and synthesis of nanostructured composites [20-24]. Such methods as melting, sintering, or mechanochemical synthesis by ball milling are used to achieve these goals for magnesium. Compared with the Mg-based hydrogen storage materials prepared by the methods mentioned above, Mg-based thin films show numerous advantages due to their interface, composition, and crystallinity being able to be accurately tailored on the nanoscale [25]. Thus, at present, many research groups continue their work on the study of the hydrogen storage properties of Mg-based thin films, for which one can refer to our previous review [26].

Doping Mg with Al leads to the formation of intermetallic compounds with a lower hydrogenation enthalpy in comparison with pure magnesium. It allows to destabilize magnesium hydride. Thus, alloying Mg with Al helps reduce the heat of reaction, increases 
the nucleation rate, and decreases the dehydrogenation temperature [27]. It should be noted that the $\mathrm{Mg}_{17} \mathrm{Al}_{12}$ phase formed during the hydrogenation process as a result of reaction between $\mathrm{Al}$ and $\mathrm{Mg}$. The hydrogen absorption and desorption processes of the $\mathrm{Mg}_{17} \mathrm{Al}_{12}$ phase are completely reversible through multiple-step reactions [27]. The phase transformation of the $\gamma-\mathrm{Mg}_{17} \mathrm{Al}_{12}$ intermetallic compound during hydrogenation and dehydrogenation processes is reported by Andreasen [28]:

$$
\begin{gathered}
\mathrm{Mg}_{17} \mathrm{Al}_{12}+9 \mathrm{H}_{2}=9 \mathrm{MgH}_{2}+4 \mathrm{Mg}_{2} \mathrm{Al}_{3} \Delta H=-74 \mathrm{~kJ} \mathrm{~mol}^{-1} \mathrm{H}_{2} \\
\mathrm{Mg}_{2} \mathrm{Al}_{3}+2 \mathrm{H}_{2}=2 \mathrm{MgH}_{2}+3 \mathrm{Al} \Delta H=-71 \mathrm{~kJ} \mathrm{~mol}^{-1} \mathrm{H}_{2}
\end{gathered}
$$

It is worth mentioning that $\mathrm{Mg}_{2} \mathrm{Al}_{3}$ would subsequently be transformed into $\mathrm{MgH}_{2}$ and $\mathrm{Al}$ only if higher hydrogenation pressure than that used for hydrogenation of $\mathrm{Mg}_{17} \mathrm{Al}_{12}$ were applied [29]. Although compared with transition metals, light metals cannot cause serious capacity loss [25], the solubility of $\mathrm{H}$ in solid Al is extremely low with atomic $\mathrm{H} / \mathrm{Al}$ fractions in the range of $10^{-6}$ to $10^{-8}$ [30]. The density functional theory (DFT) calculation in the generalized gradient approximation method performed by Ismer et al. [31] showed that the formation energy for interstitial hydrogen is significantly lower in hcp $\mathrm{Mg}$ than in fcc $\mathrm{Al}$, implying that the interstitial $\mathrm{H}$ concentration in $\mathrm{Mg}$ is more than nine orders of magnitude higher than in $\mathrm{Al}$ at room temperature.

In this paper, we theoretically studied hydrogen and aluminum binding energies in the $\mathrm{Mg}-\mathrm{Al}-\mathrm{H}$ system. The hydrogen accumulation in the magnesium and magnesiumaluminum system was experimentally investigated. The main aim of this work was to study the influence of the hydrogen and aluminum concentrations on their binding energies in the $\mathrm{Mg}-\mathrm{Al}-\mathrm{H}$ solid solution and to reveal the role of aluminum atom addition on hydrogen adsorption and accumulation in the $\mathrm{Mg}-\mathrm{H}$ solid solution. The data obtained will be useful for further research of hydrogen storage materials [32-34].

\section{Materials and Methods}

\subsection{Sample Preparation}

Samples of stainless steel 12 X18H10T with $20 \mathrm{~mm} \times 20 \mathrm{~mm} \times 1 \mathrm{~mm}$ dimensions were used as substrates. The deposition of coatings was carried out by the method of magnetron sputtering (physical vapor deposition). Sample preparation was carried out as follows: (1) grinding and polishing using silicon carbide abrasive paper (ISO from 160 to 4000); (2) exposure in the ultrasonic bath with acetone for $20 \mathrm{~min}$; (3) additional cleaning of the surface with acetone before placing it in the chamber of the "Raduga-Spectrum" installation for ion-plasma spraying; (4) removing atomic layers from the surface by lowenergy ( $2 \mathrm{keV}$ ) $\mathrm{Ar}^{+}$ion bombardment for $20 \mathrm{~min}$ in the vacuum chamber of the "Raduga Spectrum" installation. After these procedures, the prepared steel substrates were coated on one side using a magnetron system.

Pure $\mathrm{Mg}$ and $\mathrm{Mg}-10 \% \mathrm{Al}$ coatings were formed in a stationary mode using a magnetron sputtering process with a direct current source. Magnesium MG90 and Mg-10\%Al custommade targets (JSC NIIEFA, St. Petersburg, Russia) were used as cathodes for the magnetron system. Magnesium coating was deposited in argon atmosphere $(0.12 \mathrm{~Pa})$ at discharge voltage $\mathrm{U}=450 \mathrm{~V}$ under a fixed sputter voltage of $-600 \mathrm{~V}(1 \mathrm{~min})$. Discharge current was $\mathrm{I}=2.15 \mathrm{~A}$ and the deposition time was $\mathrm{t}=15 \mathrm{~min}$. Sputtering magnesium required a power of $1 \mathrm{~kW}$. For $\mathrm{Mg}-10 \% \mathrm{Al}$ coating discharge voltage was about $520 \mathrm{~V}$, sputter voltage was $-600 \mathrm{~V}(1 \mathrm{~min})$, discharge current $\mathrm{I}=2.25 \mathrm{~A}$, and deposition time $\mathrm{t}=17.5 \mathrm{~min}$. Power (power discharge stabilization) for $\mathrm{Mg}-10 \% \mathrm{Al}$ sputtering was $1.5 \mathrm{~kW}$. All these parameters allowed to obtain a stable discharge and to ensure the required thickness of each type of coating.

\subsection{Experimental Methods}

S-3400N scanning electron microscope (Hitachi, Tokyo, Japan) was used to analyze the microstructure and thickness of the obtained coatings. The detailed elemental analysis was 
carried out using color mapping for the distribution of elements on the coatings surface. Structural phase analysis was performed on an XRD-7000S diffractometer equipped with a OneSight high-speed wide-angle detector (Shimadzu, Kyoto, Japan). Analysis of diffraction patterns and identification of phases were carried out using the PDF-4+2020 database and the PowderCell 2.4 program. The study of the distribution of elements in the coatings was carried out by the method glow-discharge optical emission spectroscopy (GDOES) on a GD-Profiler 2 spectrometer equipped with a high-frequency ac-powered pulse generator (Horiba, Kyoto, Japan).

An automated complex Gas Reaction Controller (Advanced Materials Research, Pittsburgh, PA, USA) was used to perform gas-phase hydrogenation of the coatings. Hydrogen pressure of about 30 atmospheres was used for hydrogenation. The heating rate was $6{ }^{\circ} \mathrm{C} / \mathrm{min}$ and the maximum temperature was $400^{\circ} \mathrm{C}$. The samples were kept in a hydrogen atmosphere for $12 \mathrm{~h}$. The hydrogen analyzer RHEN602 (LECO, St. Joseph, CA, USA) was used to determine the hydrogen content in the coatings. The studies performed using all the above-mentioned equipment were conducted on the premises of Tomsk Polytechnic University.

\subsection{Ab Initio Calculations}

Self-consistent calculations of the total energy of a pure $\mathrm{Mg}$ and $\mathrm{Al}$, a molecule $\mathrm{H}_{2}$ and $\mathrm{Mg}-\mathrm{H}, \mathrm{Al}-\mathrm{H}$, and $\mathrm{Mg}-\mathrm{Al}-\mathrm{H}$ solid solutions were carried out within the density functional theory using the optimized norm-conserving Vanderbilt pseudopotential method [35], as implemented in the ABINIT code [36,37]. The exchange and correlation effects were described within the generalized gradient approximation in the form of Perdew-BurkeErnzerhof (PBE) [38]. The cutoff energy for the plane-wave basis was set to $816 \mathrm{eV}$. The k-point mesh in the structural optimization were set to $14 \times 14 \times 9$ for hcp $\mathrm{Mg}$ supercell, $12 \times 12 \times 12$ for fcc Al supercell, $5 \times 5 \times 3$ for hcp $\mathrm{Mg}_{16-x} \mathrm{Al}_{x} \mathrm{H}_{y}(x=0,1,2,3$ and $y=0,1,2)$ supercell (Figure 1a), $6 \times 12 \times 6$ for fcc $\mathrm{Al}_{16} \mathrm{H}_{x}(x=0,1,2)$ supercell (Figure 1b) and $5 \times 5 \times 8$ for bct $\mathrm{Mg}_{16-x} \mathrm{Al}_{x} \mathrm{H}_{32}(x=0,1)$ supercell (Figure $1 \mathrm{c}$ ). The atoms in the system were assumed to be in the equilibrium configuration when the force on each atom was below $5 \mathrm{meV} / \AA$. The hcp $\mathrm{Mg}_{16-x} \mathrm{Al}_{x} \mathrm{H}_{y}$ solid solution model was built with $\mathrm{Al}$ in the substitution sites and hydrogen in tetrahedral $(\mathrm{T})$ or octahedral $(\mathrm{O})$ interstitial sites of the supercell consisting of $2 \times 2 \times 2$ hcp $\mathrm{Mg}$ unit cell. The fcc $\mathrm{Al}_{16} \mathrm{H}_{x}$ solid solution model was built with hydrogen in tetrahedral $(\mathrm{T})$ or octahedral $(\mathrm{O})$ interstitial sites of the supercell consisting of $2 \times 1 \times 2 \mathrm{fcc} \mathrm{Al}$ unit cell. The bct $\mathrm{Mg}_{16-x} \mathrm{Al}_{x} \mathrm{H}_{32}$ model was built with $\mathrm{Al}$ in the substitution sites of $\mathrm{Mg}_{16} \mathrm{H}_{32}$ supercell consisting of $2 \times 2 \times 2$ bct $\mathrm{Mg}_{2} \mathrm{H}_{4}$ unit cell. For a more convenient discussion of results, the $\mathrm{T}$ and $\mathrm{O}$ sites in Figure 1 are enumerated.

To analyze the structural stability of the systems under consideration, the binding energies of aluminum $\left(E_{\mathrm{Al}}^{\mathrm{b}}\right)$ and hydrogen $\left(E_{\mathrm{H}}^{\mathrm{b}}\right)$ in the $\mathrm{Mg}-\mathrm{Al}-\mathrm{H}$ system were calculated:

$$
\begin{gathered}
E_{\mathrm{Al}}^{\mathrm{b}}=\frac{E_{\text {tot }}\left(\mathrm{Mg}_{16} \mathrm{H}_{\mathrm{y}}\right)+\frac{x}{16} E_{\text {tot }}\left(\mathrm{Al}_{16}\right)-E_{\text {tot }}\left(\mathrm{Mg}_{16-x} \mathrm{Al}_{x} \mathrm{H}_{\mathrm{y}}\right)-\frac{x}{16} E_{\text {tot }}\left(\mathrm{Mg}_{16}\right)}{x}, \\
E_{\mathrm{H}}^{\mathrm{b}}=\frac{E_{\text {tot }}\left(\mathrm{Mg}_{16-x} \mathrm{Al}_{x}\right)+\frac{y}{2} E_{\text {tot }}\left(\mathrm{H}_{2}\right)-E_{\text {tot }}\left(\mathrm{Mg}_{16-x} \mathrm{Al}_{x} \mathrm{H}_{\mathrm{y}}\right)}{y},
\end{gathered}
$$

Here, $E_{\text {tot }}\left(\mathrm{Al}_{16}\right)$ and $E_{\text {tot }}\left(\mathrm{Mg}_{16}\right)$ are the total energies of pure aluminum and magnesium in the presence of 16 aluminum atoms in the fcc supercell or 16 magnesium atoms in the hcp supercell, respectively;

$E_{\text {tot }}\left(\mathrm{H}_{2}\right)$ is the total energy of the hydrogen molecule;

$E_{\text {tot }}\left(\mathrm{Al}_{16} \mathrm{H}_{y}\right)$ and $E_{\text {tot }}\left(\mathrm{Mg}_{16} \mathrm{H}_{y}\right)$ are the total energies of the fcc $\mathrm{Al}-\mathrm{H}$ and the hcp $\mathrm{Mg}-\mathrm{H}$ solid solutions supercell, respectively;

$E_{\text {tot }}\left(\mathrm{Mg}_{16-x} \mathrm{Al}_{x}\right)$ and $E_{\text {tot }}\left(\mathrm{Mg}_{16-x} \mathrm{Al}_{x} \mathrm{H}_{\mathrm{y}}\right)$ are the total energies of the hcp $\mathrm{Mg}-\mathrm{Al}$ solid solution supercell and the $\mathrm{Mg}-\mathrm{Al}-\mathrm{H}$ supercell;

$x$ and $y$ are the numbers of $\mathrm{Al}$ and $\mathrm{H}$ atoms, respectively, in the $\mathrm{Al}-\mathrm{H}, \mathrm{Mg}-\mathrm{H}, \mathrm{Mg}-\mathrm{Al}$, and Mg-Al-H supercells $(x=0,1,2,3,16, y=0,1,2,32)$. 


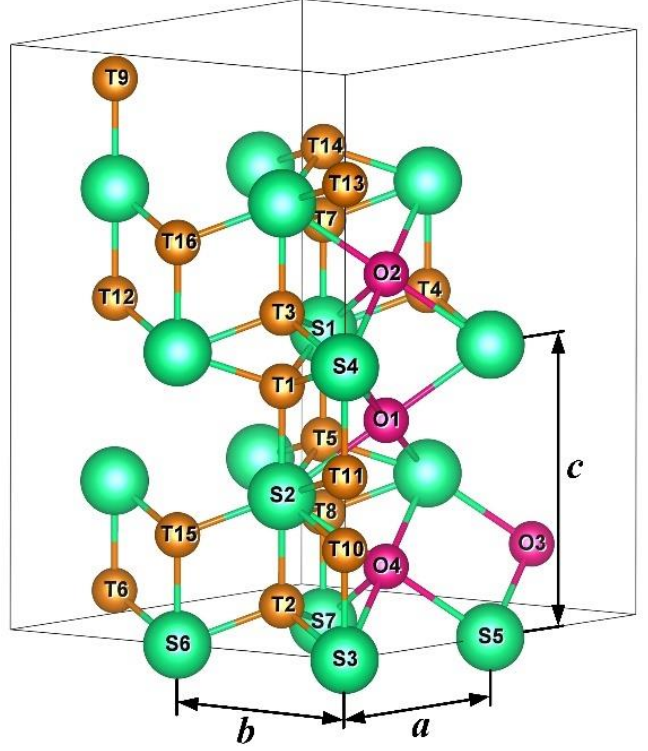

(a)

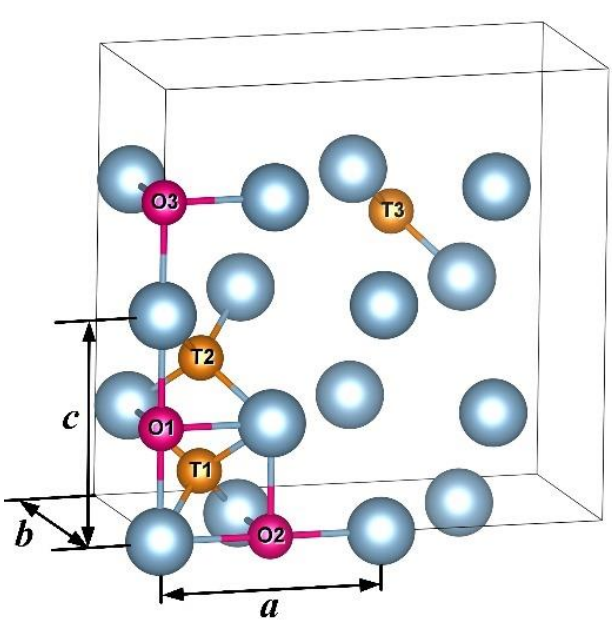

(b)

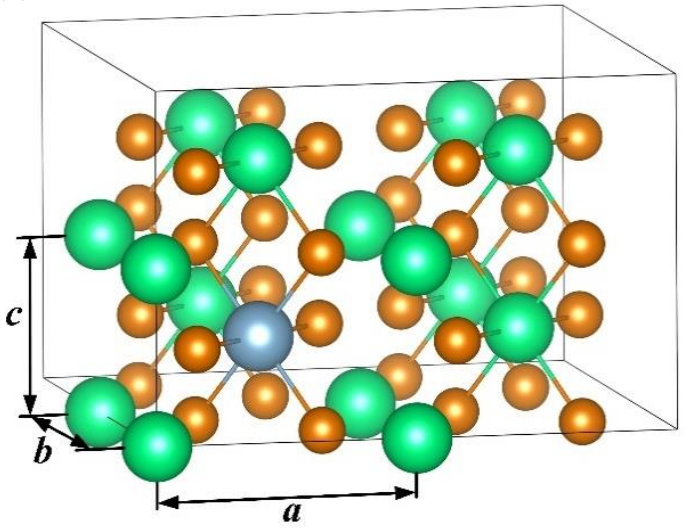

(c)

Figure 1. (a) Positions of the considered substitution sites for $\mathrm{Al}$ atoms and positions of the considered interstitial sites for $\mathrm{H}$ atoms in the hcp $\mathrm{Mg}_{16}$ supercell; (b) positions of the considered interstitial sites for $\mathrm{H}$ atoms in the fcc $\mathrm{Al}_{16}$ supercell; (c) positions of the considered substitution sites for $\mathrm{Al}$ atoms in the bct $\mathrm{Mg}_{16} \mathrm{H}_{32}$ supercell. Magnesium atoms are green, aluminum atoms are blue, tetrahedral sites are orange, and octahedral sites are pink.

To analyze the influence of the $\mathrm{H}$ and $\mathrm{Al}$ atoms on the lattice constants of the hcp $\mathrm{Mg}$ matrix, the average lattice constants were calculated:

$$
\begin{gathered}
\bar{a}=\frac{\sum_{N} a+\sum_{N} b}{2 N} \\
\bar{c}=\frac{\sum_{N} c}{N}
\end{gathered}
$$

Here, $a, b, c$ are the calculated lattice constants of hcp $\mathrm{Mg}$ matrix shown in Figure 1a for a certain calculation configuration;

$\mathrm{N}$ - the number of calculation configurations for a certain system.

\section{Results and Discussion}

\subsection{First-Principles Calculations of $\mathrm{Mg}-\mathrm{Al}-\mathrm{H}$ System}

First of all, geometry optimization of the $\mathrm{H}_{2}$ molecule and the hcp $\mathrm{Mg}$ and fcc $\mathrm{Al}$ bulk structures was conducted. The value of the total energy of the $\mathrm{H}_{2}$ molecule was calculated 
to be $-31.729 \mathrm{eV}$, very close to the value of $-31.565 \mathrm{eV}$ obtained by using the von BarthHedin exchange-correlation potential [39]. The lattice constants calculated for pure $\mathrm{Mg}$ and $\mathrm{Al}$ (Table 1) are in good agreement with the results of experimental research [40,41] and other theoretical studies [41-43]. Thus, the chosen computation parameters and the model can provide a reliable description of the $\mathrm{Al}-\mathrm{H}, \mathrm{Mg}-\mathrm{H}, \mathrm{Mg}-\mathrm{Al}$, and $\mathrm{Mg}-\mathrm{Al}-\mathrm{H}$ solid solutions.

Table 1. Lattice constants of fcc $\mathrm{Al}$ and hcp Mg.

\begin{tabular}{cccc}
\hline \multirow{2}{*}{ Elements } & \multicolumn{3}{c}{ Lattice Constants, $\mathbf{\AA}$} \\
\cline { 2 - 4 } & This Work & Experiments & Other Calculations \\
\hline $\mathrm{Al}$ & $a=4.04$ & $a=4.05[40]$ & $\begin{array}{l}a=4.021[41] \\
a=3.982[42]\end{array}$ \\
\hline $\mathrm{Mg}$ & $a=3.186, c=5.235$ & $a=3.21, c=5.213[41]$ & $\begin{array}{c}a=3.19, c=5.17[43] \\
a=3.192, c=5.206[41]\end{array}$ \\
\hline
\end{tabular}

Analyzing the results presented in Table 2, we can deduce that compared with $\mathrm{Al}-\mathrm{H}$ solid solution, the $\mathrm{Mg}-\mathrm{H}$ solid solution forms easier since the binding energy of $\mathrm{Mg}_{16} \mathrm{H}$ and $\mathrm{Mg}_{16} \mathrm{H}_{2}$ is larger than that of $\mathrm{Al}_{16} \mathrm{H}$ and $\mathrm{Al}_{16} \mathrm{H}_{2}$, respectively. The difference in the $\mathrm{H}$ binding energy in the $\mathrm{Al}-\mathrm{H}$ and $\mathrm{Mg}-\mathrm{H}$ solid solutions can be explained by three factors [31]: first, the influence of the lattice type (fcc in $\mathrm{Al}$ versus hcp in $\mathrm{Mg}$ ); second, the larger equilibrium volume in $\mathrm{Mg}$ compared to $\mathrm{Al}$; and third, the difference in the valence electron number ( $\mathrm{Mg}$ has one less than $\mathrm{Al})$. It is reported in [11] that the continuous $\mathrm{Al}$ layer on $\mathrm{Mg}$ in the $\mathrm{Mg} / \mathrm{Al}$ film system prevents hydrogen diffusion towards the Al-Mg interface at room temperature, as a result, the $\mathrm{MgH}_{2}$ phase is not formed. We believe that the blocking effect of the continuous Al layer does not arise from the diffusion of hydrogen inside the Al layer. Some justification for this hypothesis can be found in the fact that hydrogen diffusivity in $\mathrm{Al}$ (at $300 \mathrm{~K}$ ) is similar to $\mathrm{Mg}$ or slightly improved [28]. Considering the larger binding energy of $\mathrm{Mg}_{16} \mathrm{H}$ and $\mathrm{Mg}_{16} \mathrm{H}_{2}$ than that of $\mathrm{Al}_{16} \mathrm{H}$ and $\mathrm{Al}_{16} \mathrm{H}_{2}$, it can be believed that the blocking effect of the continuous Al layer is mainly caused by the difficulty in the formation of the Al-H solid solution since for the $\mathrm{Mg} / \mathrm{Al}$ film system the diffusion of hydrogen atoms through the continuous Al layer on $\mathrm{Mg}$ towards Al-Mg interface occurs only when hydrogen is solid-dissolved in Al. It was reported that a $1 \mathrm{~nm}$ $\mathrm{Al}$ interlayer grows discontinuously on magnesium, forming isolated $\mathrm{Al}$ islands which are less likely to form an alloy with $\mathrm{Mg}$ and therefore serve as heterogeneous nucleation centers to collect hydrogen atoms [11,25]. According to the above discussion, the higher hydrogen storage capacity of the $\mathrm{Mg}-\mathrm{Al}$ alloy film system can be attributed to the following factors: (1) isolated $\mathrm{Al}$ islands can be formed on the surface of $\mathrm{Mg}$ particle. It can be proposed that the volume expansion from $\mathrm{Al}$ to Al-H solid solution, as shown in Tables 1 and 2, leads to the volume expansion of the attached $\mathrm{Mg}$ lattice, which allows dispelling the accumulated elastic strain caused by the around $20 \%$ lattice expansion from the initial $\mathrm{Mg}$ metal to the rutile-type tetragonal phase of $\mathrm{MgH}_{2}$ [12], making the nucleation and growth of $\mathrm{MgH}_{2}$ fast and easy; (2) the blocking effect of the $\mathrm{MgH}_{2}$ layer can be weakened as a result of the easier hydrogen diffusion through $\mathrm{Al}$ islands or through the additional grain boundaries between $\mathrm{MgH}_{2}$ and $\mathrm{Al}$ islands than through $\mathrm{MgH}_{2}$; (3) the dispersed $\mathrm{Mg}_{17} \mathrm{Al}_{12}$ alters the hydrogenation pathway, which decreases the heat of formation of $\mathrm{MgH}_{2}$. It is also believed that $\mathrm{Mg}_{17} \mathrm{Al}_{12}$ acts as a catalyst to decrease the dissociation energy of $\mathrm{H}_{2}$ and improve the hydrogen sorption kinetics of $\mathrm{Mg}[44,45]$. In $\mathrm{Mg} / \mathrm{Al}$ film system, thermodynamically, compared with $\mathrm{Mg}-\mathrm{H}$ solid solution, the formation of Al-H solid solution is more unfavorable, thus it is difficult for hydrogen to enter the lattice of the continuous $\mathrm{Al}$ layer on $\mathrm{Mg}$ and thereby diffuse on the $\mathrm{Al}-\mathrm{Mg}$ interface or the surface of the $\mathrm{Mg}_{17} \mathrm{Al}_{12}$ phase, leading to a hydrogen storage capacity even lower than pure $\mathrm{Mg}$ film. 
Table 2. The binding energy of $\mathrm{Al}_{16} \mathrm{H}_{y}$ and $\mathrm{Mg}_{16} \mathrm{H}_{y}$. $E_{\text {calc }}^{f}$ is the calculated formation energy from previous theoretical studies for comparison.

\begin{tabular}{|c|c|c|c|c|c|c|}
\hline \multirow{2}{*}{ System } & \multicolumn{3}{|c|}{ Lattice Constants, Å } & \multirow{2}{*}{ Site of $\mathbf{H}$ Atom } & \multirow{2}{*}{ Binding Energy $E_{H}^{b}, \mathrm{eV} / \mathrm{H}$ Atom } & \multirow{2}{*}{$\begin{array}{c}\text { Other Calculated Formation } \\
\text { Energy, eV/H Atom }\end{array}$} \\
\hline & $a$ & $b$ & $c$ & & & \\
\hline \multirow{2}{*}{$\mathrm{Mg}_{16} \mathrm{H}$} & 3.203 & 3.203 & 5.196 & $\mathrm{~T}$ & -0.190 & $\mathrm{Mg}_{48} \mathrm{H}, E_{\text {calc }}^{f}=0.12^{\mathrm{a}}$ \\
\hline & 3.204 & 3.204 & 5.186 & $\mathrm{O}$ & -0.327 & $\mathrm{Mg}_{48} \mathrm{H}, E_{\text {calc }}^{f}=0.26^{\mathrm{a}}$ \\
\hline \multirow{3}{*}{$\mathrm{Mg}_{16} \mathrm{H}_{2}$} & 3.211 & 3.211 & 5.269 & $\mathrm{~T} 1, \mathrm{~T} 2$ & -0.204 & - \\
\hline & 3.172 & 3.172 & 5.427 & $\mathrm{~T} 1, \mathrm{~T} 3$ & -0.299 & - \\
\hline & 3.213 & 3.214 & 5.262 & $\mathrm{~T} 2, \mathrm{~T} 4$ & -0.204 & - \\
\hline \multirow[b]{2}{*}{$\mathrm{Al}_{16} \mathrm{H}$} & 4.059 & 4.037 & 4.059 & $\mathrm{O}$ & -0.789 & $\mathrm{Al}_{32} \mathrm{H}, E_{\text {calc }}^{f}=0.77^{\mathrm{a}}$ \\
\hline & 4.053 & 4.071 & 4.053 & $\mathrm{~T}$ & -0.680 & $\begin{array}{l}\mathrm{Al}_{32} \mathrm{H}, E_{\text {calc }}^{f}=0.69^{\mathrm{b}} \\
\mathrm{Al}_{32} \mathrm{H}, E_{\text {calc }}^{f}=0.68^{\mathrm{a}}\end{array}$ \\
\hline \multirow{6}{*}{$\mathrm{Al}_{16} \mathrm{H}_{2}$} & 4.083 & 4.088 & 4.067 & $\mathrm{O} 1, \mathrm{O} 2$ & -0.748 & - \\
\hline & 4.080 & 4.083 & 4.080 & $\mathrm{O} 1, \mathrm{O} 3$ & -0.789 & - \\
\hline & 4.083 & 4.059 & 4.083 & $\mathrm{~T} 1, \mathrm{~T} 2$ & -0.626 & - \\
\hline & 4.072 & 4.077 & 4.072 & $\mathrm{~T} 1, \mathrm{~T} 3$ & -0.721 & - \\
\hline & 4.083 & 4.088 & 4.067 & $\mathrm{O} 1, \mathrm{~T} 1$ & -0.707 & - \\
\hline & 4.080 & 4.083 & 4.080 & O1, T3 & -0.721 & - \\
\hline
\end{tabular}

${ }^{\mathrm{a}}$ Reference (DFT GGA) [31]; ${ }^{\mathrm{b}}$ Reference (DFT GGA) [30].

The formation of $\mathrm{AlH}_{3}$ was not observed during the hydrogenation of $\mathrm{Mg}-\mathrm{Al}$ in our experiment. There are two explanations for this: (1) the $\mathrm{AlH}_{3}$ formation is possible at high hydrogen pressures (more than $25 \mathrm{kbar}$ ) [28,46,47]; (2) the temperatures used to achieve acceptable kinetics for $\mathrm{MgH}_{2}$ exceed the decomposition temperature of $\mathrm{AlH}_{3}$ since $\mathrm{AlH}_{3}$ can be decomposed into $\mathrm{Al}$ and $\mathrm{H}_{2}$ at $170{ }^{\circ} \mathrm{C}$, and the decomposition enthalpy is only $10 \mathrm{~kJ} \mathrm{~mol}^{-1} \mathrm{H}_{2}$ [48].

From Table 3 and Figure 2, it can be seen that the increase of $\mathrm{H}$ atoms in the $\mathrm{Mg}$ lattice will reduce $E_{\mathrm{Al}}^{\mathrm{b}}$. This is due to the fact that in the $\mathrm{Mg}-\mathrm{H}$ solid solution, $\mathrm{Mg}-\mathrm{H}$ bonds are formed, which are stronger than $\mathrm{Mg}-\mathrm{Mg}$ bonds, leading to the more difficult substitution of $\mathrm{Mg}$ atoms by $\mathrm{Al}$ atoms. The reduced $E_{\mathrm{H}}^{\mathrm{b}}$ with the increase of $\mathrm{Al}$ atoms in the $\mathrm{Mg}$ lattice can be explained by the weaker $\mathrm{Al}-\mathrm{H}$ bonds than $\mathrm{Mg}-\mathrm{H}$ bonds. The same conclusion can also be used for Al-doped bct $\mathrm{Mg}$ hydride because the calculated results $E_{\mathrm{Al}}^{\mathrm{b}}\left(\mathrm{Mg}_{15} \mathrm{Al}\right)=-0.173 \mathrm{eV} / \mathrm{Al}$ atom, $E_{\mathrm{Al}}^{\mathrm{b}}\left(\mathrm{Mg}_{15} \mathrm{AlH}_{32}\right)=-1.779 \mathrm{eV} / \mathrm{Al}$ atom, $E_{\mathrm{H}}^{\mathrm{b}}\left(\mathrm{Mg}_{16} \mathrm{H}_{32}\right)=0.268 \mathrm{eV} / \mathrm{H}$ atom, and $E_{\mathrm{H}}^{\mathrm{b}}\left(\mathrm{Mg}_{15} \mathrm{AlH}_{32}\right)=0.218 \mathrm{eV} / \mathrm{H}$ atom show the reduction of $E_{\mathrm{Al}}^{\mathrm{b}}$ with the increase of $\mathrm{H}$ atoms in the $\mathrm{Mg}$ lattice and the reduction of $E_{\mathrm{H}}^{\mathrm{b}}$ with the increase of $\mathrm{Al}$ atoms in the $\mathrm{Mg}$ lattice.

It was reported that the relationship between lattice constants $(\AA)$ and solubility of $\mathrm{Mg}-\mathrm{Al}$ solid solution satisfied the following empirical formula [49]:

$$
\begin{aligned}
& a=2.807+4.0234 \times 10^{-3} \times(100-z) \\
& c=4.672+5.3864 \times 10^{-3} \times(100-z)
\end{aligned}
$$

where $z$ represents the mole solubility of $\mathrm{Al}$, at.\%. For $\mathrm{Mg}_{15} \mathrm{Al}, \mathrm{Mg}_{14} \mathrm{Al}_{2}$, and $\mathrm{Mg}_{13} \mathrm{Al}_{3}$ the mole solubility of $\mathrm{Al}$ are 6.25 at. $\%, 12.5$ at.\%, and 18.75 at. $\%$ respectively, the corresponding lattice constants was calculated to be $a\left(\mathrm{Mg}_{15} \mathrm{Al}\right)=3.184 \AA, c\left(\mathrm{Mg}_{15} \mathrm{Al}\right)=5.177 \AA$, $a\left(\mathrm{Mg}_{14} \mathrm{Al}_{2}\right)=3.159 \AA, c\left(\mathrm{Mg}_{14} \mathrm{Al}_{2}\right)=5.143 \AA, a\left(\mathrm{Mg}_{13} \mathrm{Al}_{3}\right)=3.134 \AA, c\left(\mathrm{Mg}_{13} \mathrm{Al}_{3}\right)=5.110 \AA$ by this empirical method, close to the average value of lattice constants calculated by Equations (5) and $(6)\left(\bar{a}\left(\mathrm{Mg}_{15} \mathrm{Al}\right)=3.201 \AA, \bar{c}\left(\mathrm{Mg}_{15} \mathrm{Al}\right)=5.143 \AA, \bar{a}\left(\mathrm{Mg}_{14} \mathrm{Al}_{2}\right)=3.155 \AA\right.$, 
$\left.\bar{c}\left(\mathrm{Mg}_{14} \mathrm{Al}_{2}\right)=5.065 \AA, \bar{a}\left(\mathrm{Mg}_{13} \mathrm{Al}_{3}\right)=3.151 \AA, \bar{c}\left(\mathrm{Mg}_{13} \mathrm{Al}_{3}\right)=5.026 \AA\right)$, which again validates the computation details.

Table 3. The binding energy of hcp $\mathrm{Mg}_{16-x} \mathrm{Al}_{x} \mathrm{H}_{y}, x=1,2,3, y=0,1,2$.

\begin{tabular}{|c|c|c|c|c|c|c|c|}
\hline \multirow{2}{*}{ System } & \multicolumn{3}{|c|}{ Lattice Constants, Å } & \multirow{2}{*}{$\begin{array}{c}\text { Substitution Site } \\
\text { of Al Atom }\end{array}$} & \multirow{2}{*}{ Site of $\mathbf{H}$ Atom } & \multicolumn{2}{|c|}{ Binding Energy } \\
\hline & $a$ & $b$ & $c$ & & & $E_{A l}^{b}, \mathrm{eV} / \mathrm{Al}$ Atom & $E_{H}^{b}, \mathrm{eV} / \mathrm{H}$ Atom \\
\hline $\mathrm{Mg}_{15} \mathrm{Al}$ & 3.201 & 3.201 & 5.143 & S1 & - & -0.173 & - \\
\hline \multirow{3}{*}{$\mathrm{Mg}_{14} \mathrm{Al}_{2}$} & 3.168 & 3.169 & 5.044 & $\mathrm{~S} 1, \mathrm{~S} 2$ & - & -0.133 & - \\
\hline & 3.126 & 3.126 & 5.108 & S1, S3 & - & -0.146 & - \\
\hline & 3.169 & 3.169 & 5.043 & $\mathrm{~S} 1, \mathrm{~S} 4$ & - & -0.105 & - \\
\hline \multirow{2}{*}{$\mathrm{Mg}_{13} \mathrm{Al}_{3}$} & 3.172 & 3.172 & 5.004 & S5, S6, S7 & - & -0.083 & - \\
\hline & 3.131 & 3.130 & 5.048 & $\mathrm{~S} 1, \mathrm{~S} 2, \mathrm{~S} 6$ & - & -0.137 & - \\
\hline \multirow{2}{*}{$\mathrm{Mg}_{15} \mathrm{AlH}$} & 3.211 & 3.211 & 5.141 & S1 & T5 & -0.282 & -0.299 \\
\hline & 3.206 & 3.206 & 5.149 & S1 & T6 & -0.201 & -0.218 \\
\hline \multirow{3}{*}{$\mathrm{Mg}_{15} \mathrm{AlH}_{2}$} & 3.166 & 3.166 & 5.342 & S1 & $\mathrm{T} 5, \mathrm{~T} 7$ & -0.310 & -0.272 \\
\hline & 3.167 & 3.254 & 5.076 & S1 & $\mathrm{O} 1, \mathrm{O} 2$ & -0.364 & -0.299 \\
\hline & 3.211 & 3.211 & 5.142 & S1 & $\mathrm{T} 6, \mathrm{O} 3$ & -0.310 & -0.272 \\
\hline \multirow{5}{*}{$\mathrm{Mg}_{14} \mathrm{Al}_{2} \mathrm{H}$} & 3.173 & 3.173 & 5.064 & $\mathrm{~S} 1, \mathrm{~S} 4$ & T5 & -0.173 & -0.327 \\
\hline & 3.169 & 3.169 & 5.067 & $\mathrm{~S} 1, \mathrm{~S} 4$ & T8 & -0.133 & -0.245 \\
\hline & 3.174 & 3.174 & 5.063 & $\mathrm{~S} 1, \mathrm{~S} 4$ & $\mathrm{~T} 2$ & -0.119 & -0.218 \\
\hline & 3.200 & 3.200 & 5.004 & $\mathrm{~S} 1, \mathrm{~S} 4$ & O3 & -0.187 & -0.354 \\
\hline & 3.176 & 3.176 & 5.010 & $\mathrm{~S} 1, \mathrm{~S} 4$ & $\mathrm{O} 4$ & -0.187 & -0.354 \\
\hline \multirow{5}{*}{$\mathrm{Mg}_{14} \mathrm{Al}_{2} \mathrm{H}_{2}$} & 3.168 & 3.204 & 5.125 & $\mathrm{~S} 1, \mathrm{~S} 4$ & T5, T1 & -0.214 & -0.313 \\
\hline & 3.174 & 3.174 & 5.041 & $\mathrm{~S} 1, \mathrm{~S} 4$ & O3, Т9 & -0.133 & -0.231 \\
\hline & 3.168 & 3.168 & 5.147 & $\mathrm{~S} 1, \mathrm{~S} 4$ & T5, T7 & -0.214 & -0.313 \\
\hline & 3.167 & 3.167 & 5.135 & $\mathrm{~S} 1, \mathrm{~S} 4$ & $\mathrm{~T} 10, \mathrm{~T} 7$ & -0.160 & -0.259 \\
\hline & 3.172 & 3.172 & 5.122 & $\mathrm{~S} 1, \mathrm{~S} 4$ & $\mathrm{~T} 11, \mathrm{~T} 8$ & -0.228 & -0.327 \\
\hline \multirow{2}{*}{$\mathrm{Mg}_{13} \mathrm{Al}_{3} \mathrm{H}$} & 3.164 & 3.169 & 5.043 & S5, S6, S7 & $\mathrm{T} 2$ & -0.164 & -0.435 \\
\hline & 3.169 & 3.169 & 5.039 & S5, S6, S7 & $\mathrm{T} 12$ & -0.110 & -0.272 \\
\hline \multirow{5}{*}{$\mathrm{Mg}_{13} \mathrm{Al}_{3} \mathrm{H}_{2}$} & 3.167 & 3.167 & 5.072 & S5, S6, S7 & $\mathrm{T} 10, \mathrm{~T} 13$ & -0.083 & -0.204 \\
\hline & 3.136 & 3.136 & 5.144 & S5, S6, S7 & T8, T14 & -0.183 & -0.354 \\
\hline & 3.160 & 3.204 & 5.067 & S5, S6, S7 & T8, T15 & -0.192 & -0.367 \\
\hline & 3.171 & 3.172 & 5.118 & S5, S6, S7 & T7, T16 & -0.146 & -0.299 \\
\hline & 3.133 & 3.133 & 5.194 & S5, S6, S7 & T5, T7 & -0.137 & -0.286 \\
\hline
\end{tabular}

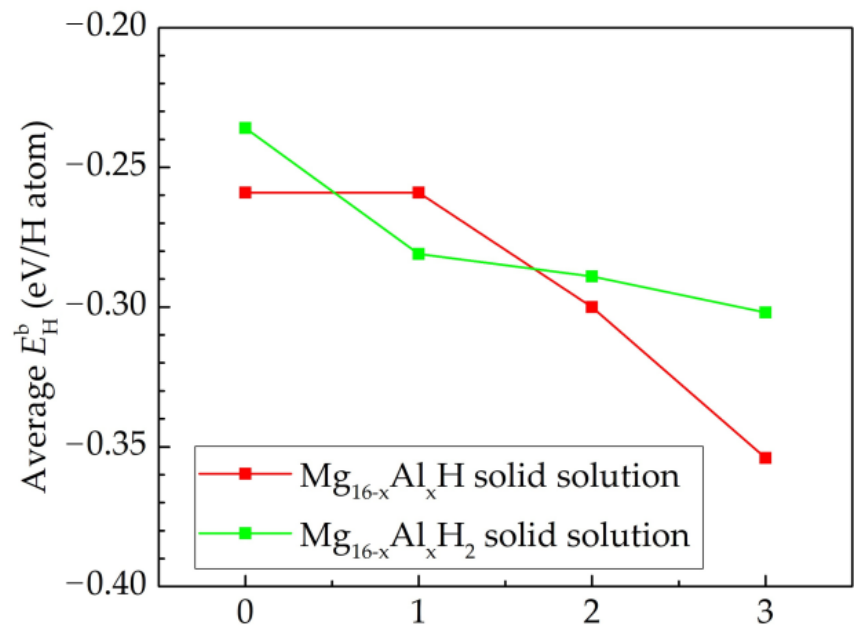

Aluminum atom number $x$ in the supercell (a)

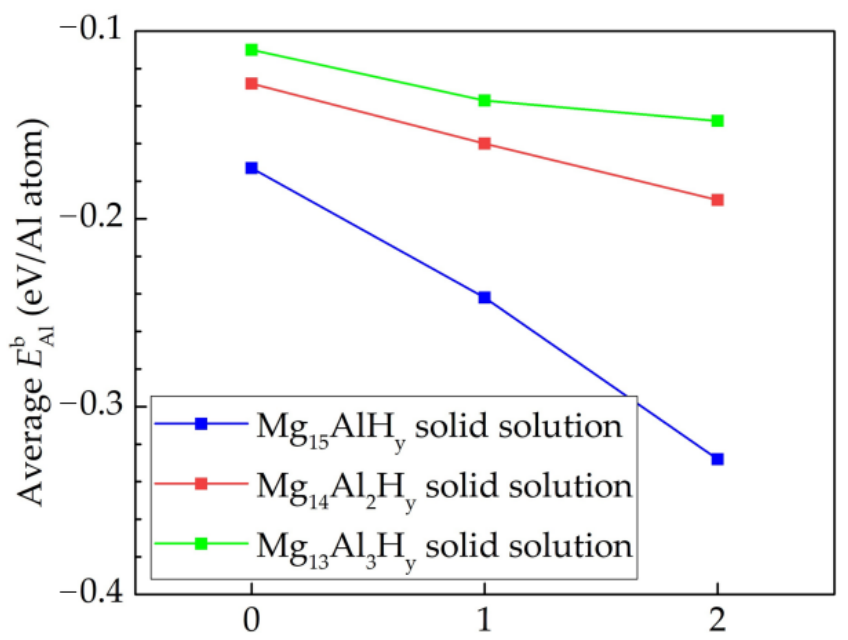

Hydrogen atom number $y$ in the supercell

(b)

Figure 2. (a) Effect of $\mathrm{Al}$ atom on the average $E_{\mathrm{H}}^{\mathrm{b}}$ of hcp $\mathrm{Mg}_{16-x} \mathrm{Al}_{x} \mathrm{H}_{y}$ solid solution $(x=0,1,2,3$, $y=1,2)$; (b) effect of $\mathrm{H}$ atom on the average $E_{\mathrm{Al}}^{\mathrm{b}}$ of hcp $\mathrm{Mg}_{16-x} \mathrm{Al}_{x} \mathrm{H}_{y}$ solid solution $(x=1,2,3$, $y=0,1,2)$. 
From Figure 3, it can be seen that increasing the number of aluminum atoms in the hcp Mg lattice slightly decreases the parameter $c$, while adding two $\mathrm{H}$ atom in the hcp $\mathrm{Mg}$ lattice slightly increases this parameter. The addition of $\mathrm{Al}$ and $\mathrm{H}$ atoms to the hcp $\mathrm{Mg}$ lattice has almost no effect on its constant $a$.

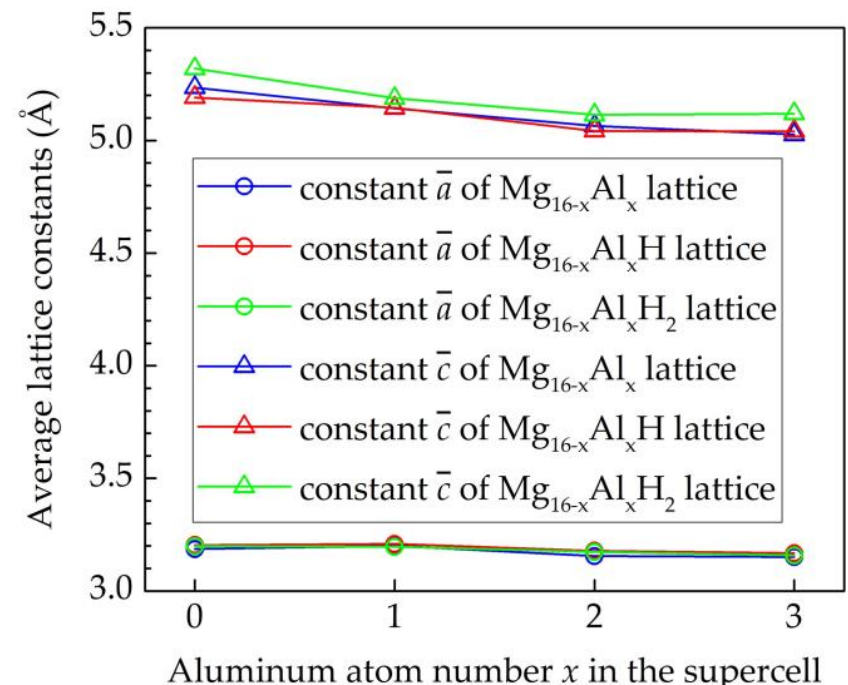

Figure 3. Dependence of the lattice constants of hcp $\mathrm{Mg}_{16-x} \mathrm{Al}_{x} \mathrm{H}_{y}(x=0,1,2,3, y=0,1,2)$ on $\mathrm{Al}$ and $\mathrm{H}$ atoms.

\subsection{Experimental Research of $\mathrm{Mg}-\mathrm{Al}-\mathrm{H}$ System}

Images of a transverse cleavage are shown in Figure 4. Analysis of the images showed that the coatings of pure magnesium have a pronounced columnar structure with the presence of intergranular pores (Figure 4a).

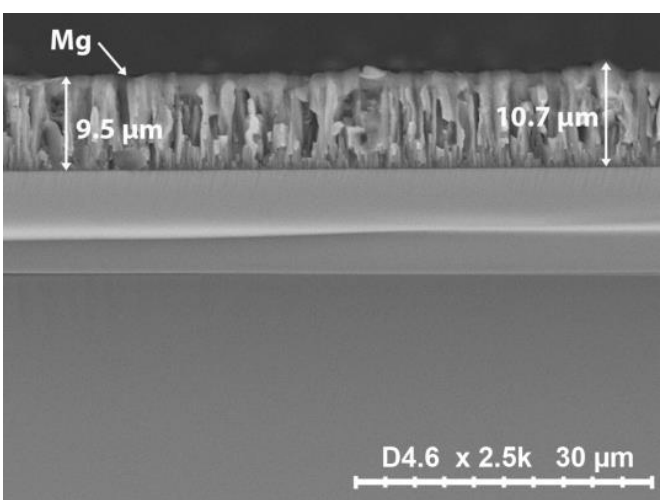

(a)

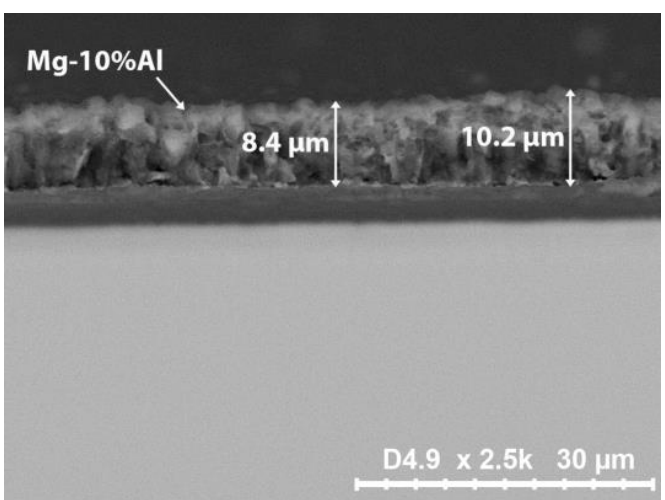

(b)

Figure 4. SEM images of a transverse cleavage of (a) Mg coating; (b) Mg-10\%Al coating.

At the same time, magnesium coatings have a fairly uniform thickness with deviations within $\pm 600 \mathrm{~nm}$. The coatings obtained from the $\mathrm{Mg}-10 \% \mathrm{Al}$ alloy have a more porous microstructure, which is caused by a more uneven grain growth and, as a consequence, a higher thickness heterogeneity (Figure $4 \mathrm{~b}$ ). Thickness deviations for $\mathrm{Mg}-10 \% \mathrm{Al}$ coating were $\pm 900 \mathrm{~nm}$. The detailed elemental analysis was carried out using color mapping for the distribution of elements on the coatings surface. Figure 5a,b shows the representative scanning electron micrograph of $\mathrm{Mg}$ and $\mathrm{Mg}-10 \% \mathrm{Al}$ coatings, respectively, with their corresponding color mapping.

In both cases, microparticles of the sprayed material are observed on the surface; however, the main area of the coatings is a plateau. It is clear from the color mapping of the pure magnesium coating that $\mathrm{Mg}$ is homogeneously distributed on the surface. $\mathrm{O}$ and 
$\mathrm{C}$ are present in small amounts and are concentrated in the unevenness of the coating relief. $\mathrm{Al}$ is not present on the coating surface. Element distribution maps for $\mathrm{Mg}-10 \% \mathrm{Al}$ coating indicate a homogeneous distribution of $\mathrm{Mg}$ and $\mathrm{Al}$ on the surface. Elements such as $\mathrm{O}$ and $\mathrm{C}$ are also present in very small amounts.

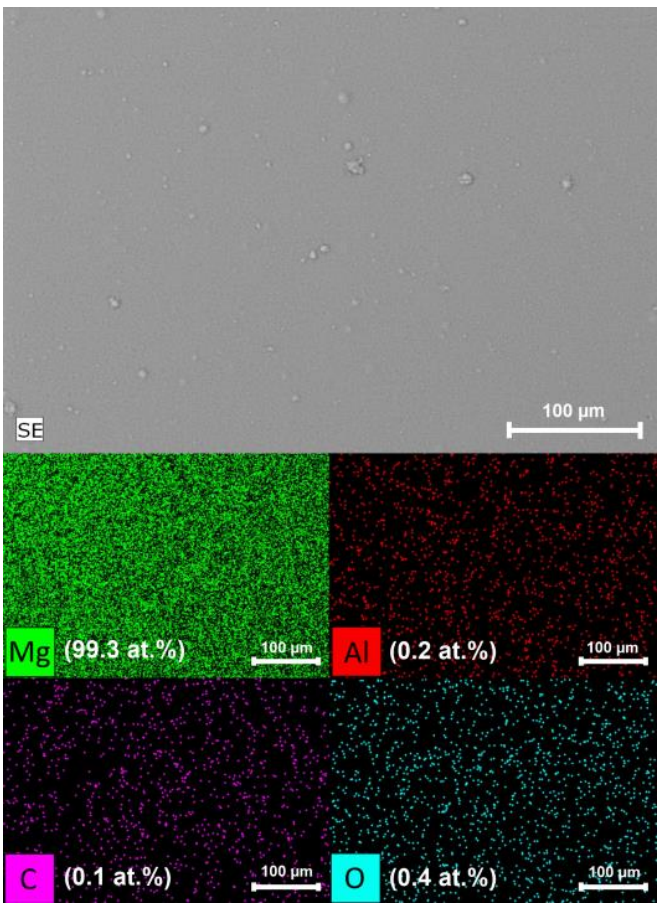

(a)

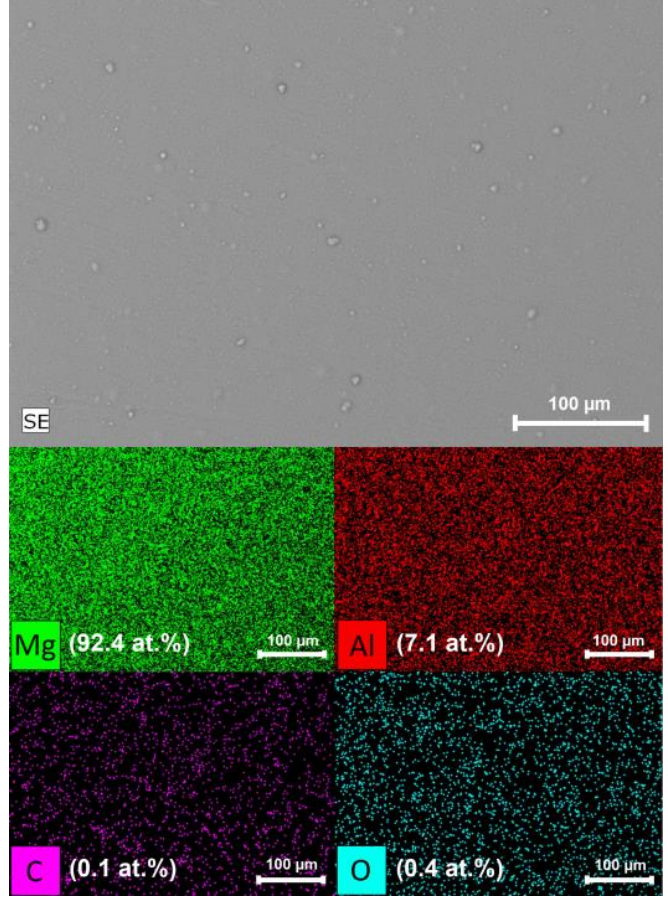

(b)

Figure 5. SEM images and elemental mapping from the surface of (a) $\mathrm{Mg}$ coating; (b) $\mathrm{Mg}-10 \% \mathrm{Al}$ coating.

Figure 6 shows the results of elements distribution investigation in the samples with (a) $\mathrm{Mg}$ coating; (b) $\mathrm{Mg}-10 \% \mathrm{Al}$ coating. Analyzing depth distributions of the different chemical elements shown in Figure 6, it can be concluded that the $\mathrm{Mg}$ and $\mathrm{Mg}-10 \% \mathrm{Al}$ coatings were applied uniformly. It also has to be noted that, due to the formation of a multiphase system, irregularities in the luminescence intensities are observed for samples with $\mathrm{Mg}-10 \% \mathrm{Al}$ coating. The total thickness of the $\mathrm{Mg}$ and $\mathrm{Mg}-10 \% \mathrm{Al}$ coatings was about $10 \mu \mathrm{m}$.

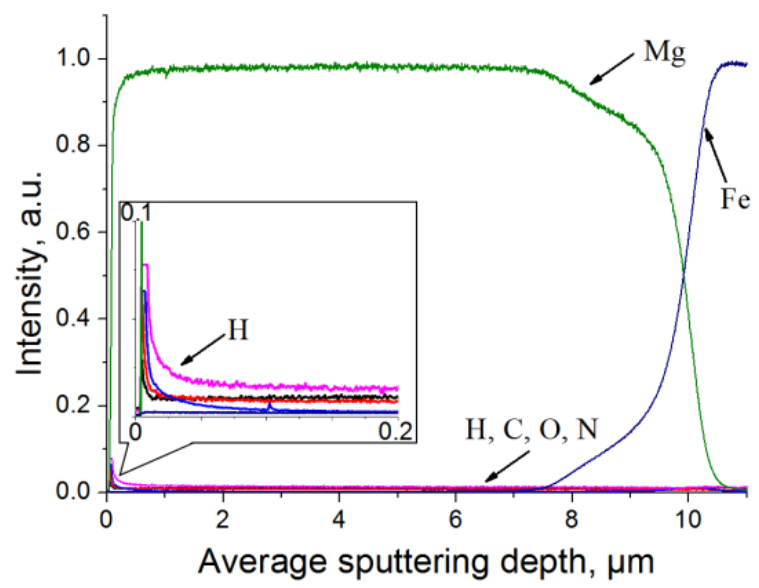

(a)

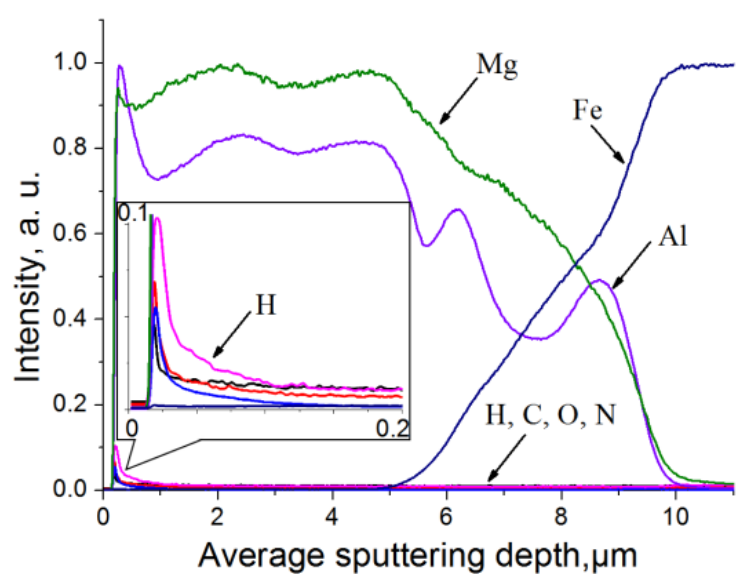

(b)

Figure 6. Depth distribution of chemical elements for samples with (a) $\mathrm{Mg}$ coating; (b) $\mathrm{Mg}-10 \% \mathrm{Al}$ coating. The insets represent the hydrogen distribution in the coatings in more detail. 
For both samples, it can be seen that hydrogen is not observed either in the coating or in the metal substrate. A small amount of hydrogen is contained on the surface of the coatings (the insets in Figure 6). This may be due to surface contamination as well as the presence of these gases in the atmosphere.

To determine the hydrogen content in the coatings, the method of extraction in an inert gas medium was used, which was carried out using a LECO RHEN602 gas analyzer. The relative error of this method is $\pm 2.5 \%$. The hydrogen content of the sample coated with magnesium and $\mathrm{Mg}-10 \% \mathrm{Al}$ was $7.4 \mathrm{ppm}$ and $5.3 \mathrm{ppm}$, respectively. This indicates that there is no hydrogen present in the samples.

The depth distributions of the different chemical elements for samples after hydrogenation is shown in Figure 7.

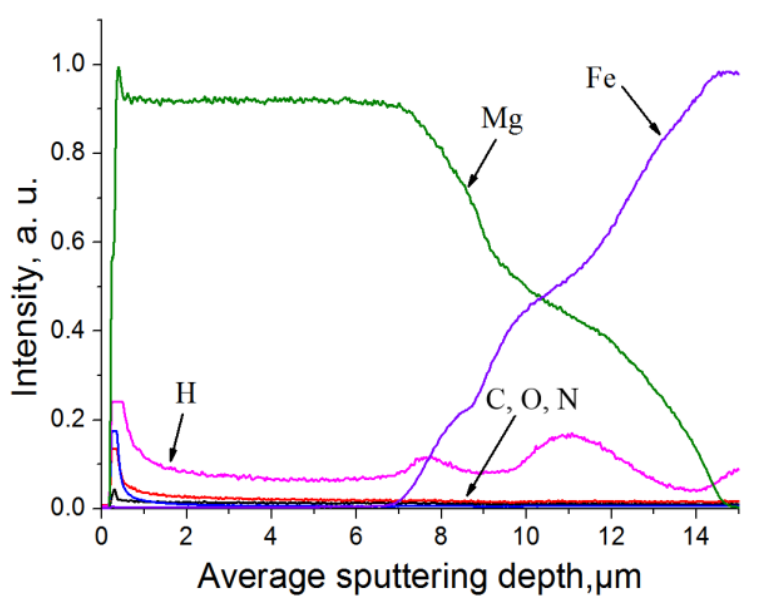

(a)

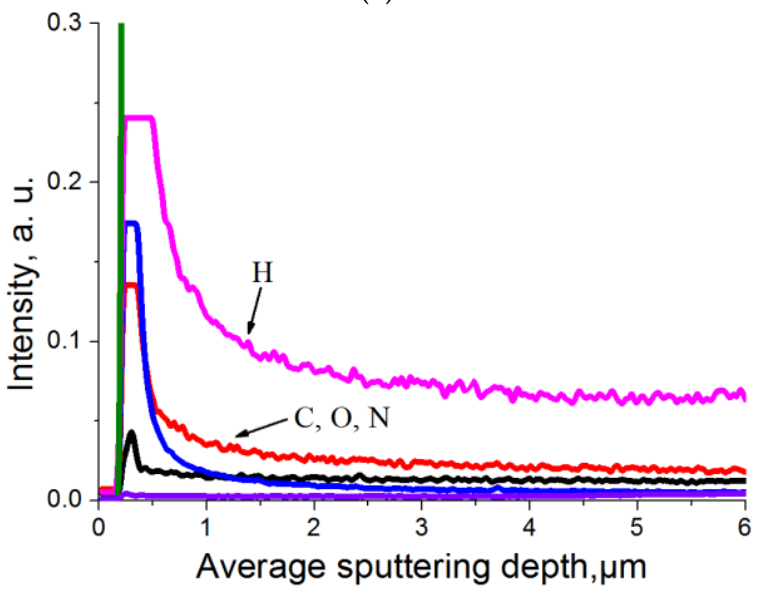

(c)

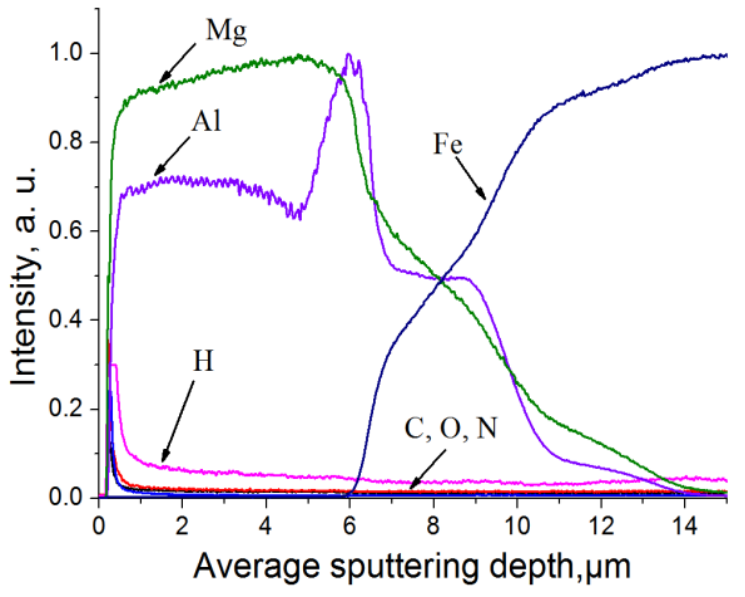

(b)

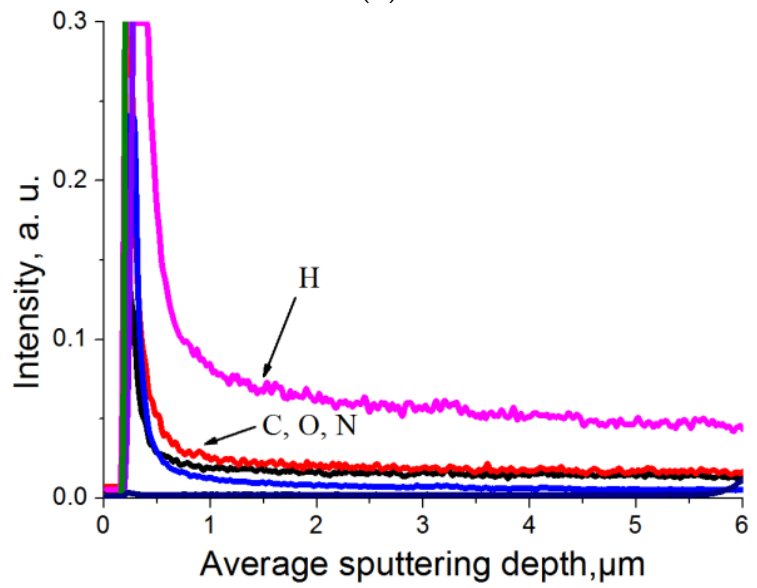

(d)

Figure 7. Depth distribution of chemical elements for samples with (a) Mg coating; (b) $\mathrm{Mg}-10 \% \mathrm{Al}$ coating after hydrogenation during $10 \mathrm{~h}$ and $30 \mathrm{~atm}$. The figures $(\mathbf{c}, \mathbf{d})$ represent the hydrogen distribution in the coatings in more detail.

It can be seen that a certain amount of hydrogen is contained on the surface of the coatings. In addition, for a magnesium coating, hydrogen is uniformly distributed in the coating, and an increased concentration of hydrogen is observed at the coating-substrate interface (Figure 7c). This may be due to the formation of voids or other defects in which hydrogen accumulates. Thus, the uniform distribution of hydrogen in the coating indicates the penetration of hydrogen atoms into the bulk of the coating. For the $\mathrm{Mg}-10 \% \mathrm{Al}$ sample, a hydrogen distribution gradient in the coating is observed (Figure 7d). This is consistent with theoretical calculations. Aluminum inhibits hydrogen diffusion due to the less favorable condition for hydrogen to be in the magnesium-aluminum system. The hydrogen content 
of the sample coated with magnesium and $\mathrm{Mg}-10 \% \mathrm{Al}$ after hydrogenation was $13 \mathrm{ppm}$ and $10 \mathrm{ppm}$, respectively.

\section{Conclusions}

Analysis of the obtained experimental data showed that a hydrogen distribution gradient is observed in the magnesium-aluminum coating, with more hydrogen on the surface and less in the bulk. In addition, the hydrogen content in the magnesium-aluminum system is lower compared to pure magnesium. This is due to the fact that the hydrogen binding energy in the magnesium-aluminum system is significantly lower compared to pure magnesium. This leads to the fact that it is less favorable for hydrogen to be in the magnesium-aluminum system; therefore, hydrogen accumulates on the surface during hydrogenation, while the diffusion of hydrogen into the bulk of the magnesium-aluminum system occurs more slowly compared to pure magnesium. In addition, it was revealed that increasing the aluminum and hydrogen concentrations in the $\mathrm{Mg}-\mathrm{Al}-\mathrm{H}$ solid solution slightly distort the hcp Mg lattice along the hexagonal axis and has almost no effect on the lattice constant in the basal plane. Thus, we can conclude that on the basis of theoretical and experimental studies, the accumulation of hydrogen in the form of a solid solution is more preferable in pure magnesium than in magnesium with aluminum. However, it is of interest to conduct such studies on the effect of aluminum on the hydrogen accumulation in magnesium hydrides.

Author Contributions: J.L. conducted theoretical research; V.N.K. carried out the organization of the workflow and preparation of the article; R.R.E. conducted the experiments on hydrogenation and performed the XRD tests; V.N.K. and L.A.S. performed the analysis of the results. All authors have read and agreed to the published version of the manuscript.

Funding: This research received no external funding.

Institutional Review Board Statement: Not applicable.

Informed Consent Statement: Not applicable.

Data Availability Statement: The raw/processed data required to reproduce these findings cannot be shared at this time as the data also forms part of an ongoing study.

Acknowledgments: This work was carried out within the framework of the Competitiveness Enhancement Program of National Research Tomsk Polytechnic University.

Conflicts of Interest: The authors declare no conflict of interest.

\section{References}

1. Baran, A.; Polanski, M. Magnesium-Based Materials for Hydrogen Storage-A Scope Review. Materials 2020, 13, 3993. [CrossRef] [PubMed]

2. Li, B.; Li, J.D.; Zhao, H.J.; Yu, X.Q.; Shao, H.Y. Mg-based metastable nano alloys for hydrogen storage. Int. J. Hydrogen Energy 2019, 44, 6007-6018. [CrossRef]

3. Zykov, B.M.; Krasnenkova, T.M.; Lazba, B.A.; Markoliya, A.I. Optimization of Magnesium-Based Solid-State Hydrogen Storage for Vehicles. Tech. Phys. 2020, 65, 946-956. [CrossRef]

4. Zhang, X.L.; Liu, Y.F.; Zhang, X.; Hu, J.J.; Gao, M.X.; Pan, H.G. Empowering hydrogen storage performance of MgH2 by nanoengineering and nanocatalysis. Mater. Today Nano 2020, 9, 100064. [CrossRef]

5. Ouyang, L.Z.; Liu, F.; Wang, H.; Liu, J.W.; Yang, X.S.; Sun, L.X.; Zhu, M. Magnesium -based hydrogen storage compounds: A review. J. Alloys Compd. 2020, 832, 154865. [CrossRef]

6. Zhang, J.G.; Zhu, Y.F.; Yao, L.L.; Xu, C.; Liu, Y.N.; Li, L.Q. State of the art multi-strategy improvement of Mg-based hydrides for hydrogen storage. J. Alloys Compd. 2019, 782, 796-823. [CrossRef]

7. Laptev, R.S.; Kudiiarov, V.N.; Bordulev, Y.S.; Mikhaylov, A.A.; Lider, A.M. Gas-phase hydrogenation influence on defect behavior in titanium-based hydrogen-storage material. Prog. Nat. Sci. Mater. Int. 2017, 27, 105-111. [CrossRef]

8. Lyu, J.Z.; Kudiiarov, V.; Lider, A. An Overview of the Recent Progress in Modifications of Carbon Nanotubes for Hydrogen Adsorption. Nanomaterials 2020, 10, 255. [CrossRef]

9. Kudiiarov, V.; Lyu, J.Z.; Semenov, O.; Lider, A.; Chaemchuen, S.; Verpoort, F. Prospects of hybrid materials composed of MOFs and hydride-forming metal nanoparticles for light-duty vehicle hydrogen storage. Appl. Mater. Today 2021, 25, 101208. [CrossRef] 
10. Kudiiarov, V.N.; Kashkarov, E.B.; Syrtanov, M.S.; Lider, A.M. Hydrogen sorption by Ni-coated titanium alloy VT1-0. Int. J. Hydrogen Energy 2017, 42, 10604-10610. [CrossRef]

11. Pacanowski, S.; Wachowiak, M.; Jablonski, B.; Szymanski, B.; Smardz, L. Interface mixing and hydrogen absorption in Pd/Mg and $\mathrm{Pd} / \mathrm{Al} / \mathrm{Mg}$ thin films. Int. J. Hydrogen Energy 2021, 46, 806-813. [CrossRef]

12. Yartys, V.A.; Lototskyy, M.V.; Akiba, E.; Albert, R.; Antonov, V.E.; Ares, J.R.; Baricco, M.; Bourgeois, N.; Buckley, C.E.; von Colbe, J.M.B.; et al. Magnesium based materials for hydrogen based energy storage: Past, present and future. Int. J. Hydrogen Energy 2019, 44, 7809-7859. [CrossRef]

13. Hao, S.Q.; Sholl, D.S. Hydrogen diffusion in $\mathrm{MgH} 2$ and $\mathrm{NaMgH} 3$ via concerted motions of charged defects. Appl. Phys. Lett. 2008, 93, 251901. [CrossRef]

14. Zhang, L.C.; Wang, K.; Liu, Y.F.; Zhang, X.; Hu, J.J.; Gao, M.X.; Pan, H.G. Highly active multivalent multielement catalysts derived from hierarchical porous TiNb2O7 nanospheres for the reversible hydrogen storage of MgH2. Nano Res. 2021, 14, 148-156. [CrossRef]

15. Zhang, L.T.; Sun, Z.; Yao, Z.D.; Yang, L.; Yan, N.H.; Lu, X.; Xiao, B.B.; Zhu, X.Q.; Chen, L.X. Excellent catalysis of Mn3O4 nanoparticles on the hydrogen storage properties of $\mathrm{MgH} 2$ : An experimental and theoretical study. Nanoscale Adv. 2020, 2, 1666-1675. [CrossRef]

16. El Khatabi, M.; Bhihi, M.; Naji, S.; Labrim, H.; Benyoussef, A.; El Kenz, A.; Loulidi, M. Study of doping effects with 3d and 4d-transition metals on the hydrogen storage properties of MgH2. Int. J. Hydrogen Energy 2016, 41, 4712-4718. [CrossRef]

17. Zhang, Y.; Zhuang, X.Y.; Zhu, Y.F.; Wan, N.; Li, L.Q.; Dong, J. Synergistic effects of TiH2 and Pd on hydrogen desorption performances of MgH2. Int. J. Hydrogen Energy 2015, 40, 16338-16346. [CrossRef]

18. Zhang, J.; He, L.; Yao, Y.; Zhou, X.J.; Yu, L.P.; Lu, X.Z.; Zhou, D.W. Catalytic effect and mechanism of NiCu solid solutions on hydrogen storage properties of MgH2. Renew. Energy 2020, 154, 1229-1239. [CrossRef]

19. Zhang, L.T.; Cai, Z.L.; Yao, Z.D.; Ji, L.; Sun, Z.; Yan, N.H.; Zhang, B.Y.; Xiao, B.B.; Du, J.; Zhu, X.Q.; et al. A striking catalytic effect of facile synthesized ZrMn2 nanoparticles on the de/rehydrogenation properties of MgH2. J. Mater. Chem. A 2019, 7, 5626-5634. [CrossRef]

20. Lyu, J.Z.; Lider, A.; Kudiiarov, V. Using Ball Milling for Modification of the Hydrogenation/Dehydrogenation Process in Magnesium-Based Hydrogen Storage Materials: An Overview. Metals 2019, 9, 768. [CrossRef]

21. Ding, Z.; Li, H.; Shaw, L. New insights into the solid-state hydrogen storage of nanostructured LiBH4-MgH2 system. Chem. Eng. J. 2020, 385, 123856. [CrossRef]

22. Lu, C.; Ma, Y.L.; Li, F.; Zhu, H.; Zeng, X.Q.; Ding, W.J.; Deng, T.; Wu, J.B.; Zou, J.X. Visualization of fast "hydrogen pump" in core-shell nanostructured Mg@Pt through hydrogen-stabilized Mg3Pt. J. Mater. Chem. A 2019, 7, 14629-14637. [CrossRef]

23. Lototskyy, M.; Goh, J.; Davids, M.W.; Linkov, V.; Khotseng, L.; Ntsendwana, B.; Denys, R.; Yartys, V.A. Nanostructured hydrogen storage materials prepared by high-energy reactive ball milling of magnesium and ferrovanadium. Int. J. Hydrogen Energy 2019, 44, 6687-6701. [CrossRef]

24. Gattia, D.M.; Jangir, M.; Jain, I.P. Study on nanostructured $\mathrm{MgH} 2$ with Fe and its oxides for hydrogen storage applications. J. Alloys Compd. 2019, 801, 188-191. [CrossRef]

25. Xin, G.B.; Yang, J.Z.; Zhang, G.Q.; Zheng, J.; Li, X.G. Promising hydrogen storage properties and potential applications of Mg-Al-Pd trilayer films under mild conditions. Dalton Trans. 2012, 41, 11555-11558. [CrossRef]

26. Lyu, J.Z.; Lider, A.M.; Kudiiarov, V.N. An overview of progress in Mg-based hydrogen storage films. Chin. Phys. B 2019, $28,098801$. [CrossRef]

27. Niyomsoan, S.; Leiva, D.R.; Silva, R.A.; Chanchetti, L.F.; Shahid, R.N.; Scudino, S.; Gargarella, P.; Botta, W.J. Effects of graphite addition and air exposure on ball-milled Mg-Al alloys for hydrogen storage. Int. J. Hydrogen Energy 2019, 44, 23257-23266. [CrossRef]

28. Andreasen, A. Hydrogenation properties of Mg-Al alloys. Int. J. Hydrogen Energy 2008, 33, 7489-7497. [CrossRef]

29. Ismail, M. The hydrogen storage properties of destabilized MgH2-AlH3 (2:1) system. Mater. Today Proc. 2016,3, S80-S87. [CrossRef]

30. Wolverton, C.; Ozolins, V.; Asta, M. Hydrogen in aluminum: First-principles calculations of structure and thermodynamics. Phys. Rev. B 2004, 69, 144109. [CrossRef]

31. Ismer, L.; Park, M.S.; Janotti, A.; Van de Walle, C.G. Interactions between hydrogen impurities and vacancies in $\mathrm{Mg}$ and $\mathrm{Al}$ : A comparative analysis based on density functional theory. Phys. Rev. B 2009, 80, 184110. [CrossRef]

32. Zhao, S.; Wang, H.; Liu, J. Exploring the Hydrogen-Induced Amorphization and Hydrogen Storage Reversibility of Y (Sc) 0.95 Ni2 Laves Phase Compounds. Materials 2021, 14, 276. [CrossRef] [PubMed]

33. Somo, T.R.; Davids, M.W.; Lototskyy, M.V.; Hato, M.J.; Modibane, K.D. Improved Hydrogenation Kinetics of TiMn1.52 Alloy Coated with Palladium through Electroless Deposition. Materials 2021, 14, 1833. [CrossRef] [PubMed]

34. Grigorova, E.; Tzvetkov, P.; Todorova, S.; Markov, P.; Spassov, T. Facilitated Synthesis of Mg2Ni Based Composites with Attractive Hydrogen Sorption Properties. Materials 2021, 14, 1936. [CrossRef] [PubMed]

35. Hamann, D.R. Optimized norm-conserving Vanderbilt pseudopotentials. Phys. Rev. B 2013, 88, 085117. [CrossRef]

36. Gonze, X.; Amadon, B.; Antonius, G.; Arnardi, F.; Baguet, L.; Beuken, J.M.; Bieder, J.; Bottin, F.; Bouchet, J.; Bousquet, E.; et al. The ABINIT project: Impact, environment and recent developments. Comput. Phys. Commun. 2020, 248, 107042. [CrossRef] 
37. Romero, A.H.; Allan, D.C.; Amadon, B.; Antonius, G.; Applencourt, T.; Baguet, L.; Bieder, J.; Bottin, F.; Bouchet, J.; Bousquet, E.; et al. ABINIT: Overview and focus on selected capabilities. J. Chem. Phys. 2020, 152, 124102. [CrossRef]

38. Perdew, J.P.; Burke, K.; Ernzerhof, M. Generalized gradient approximation made simple. Phys. Rev. Lett. 1996, 77, 3865-3868. [CrossRef]

39. Nakamura, H.; Nguyen-Manh, D.; Pettifor, D.G. Electronic structure and energetics of LaNi5, alpha-La2Ni10H and betaLa2Ni10H14. J. Alloys Compd. 1998, 281, 81-91. [CrossRef]

40. Zope, R.R.; Mishin, Y. Interatomic potentials for atomistic simulations of the Ti-Al system. Phys. Rev. B 2003, 68, 024102. [CrossRef]

41. Liu, Y.; Huang, Y.C.; Xiao, Z.B.; Reng, X.W. Study of Adsorption of Hydrogen on Al, Cu, Mg, Ti Surfaces in Al Alloy Melt via First Principles Calculation. Metals 2017, 7, 21. [CrossRef]

42. Wang, J.W.; Gong, H.R. Adsorption and diffusion of hydrogen on Ti, Al, and TiAl surfaces. Int. J. Hydrogen Energy 2014, 39, 6068-6075. [CrossRef]

43. Wu, G.; Zhang, J.; Wu, Y.; Li, Q.; Chou, K.; Bao, X. First-Principle Calculations of the Adsorption, Dissociation and Diffusion of Hydrogen on the Mg (0001) Surface. Acta Phys. Chim. Sin. 2008, 24, 55-60. [CrossRef]

44. Huang, S.J.; Chiu, C.; Chou, T.Y.; Rabkin, E. Effect of equal channel angular pressing (ECAP) on hydrogen storage properties of commercial magnesium alloy AZ61. Int. J. Hydrogen Energy 2018, 43, 4371-4380. [CrossRef]

45. Crivello, J.C.; Nobuki, T.; Kato, S.; Abe, M.; Kuji, T. Hydrogen absorption properties of the $\gamma$-Mg17Al12 phase and its Al-richer domain. J. Alloys Compd. 2007, 446, 157-161. [CrossRef]

46. Wang, Y.; Yan, J.A.; Chou, M.Y. Electronic and vibrational properties of gamma-AlH3. Phys. Rev. B 2008, 77, 014101. [CrossRef]

47. Savic, M.; Radakovic, J.; Batalovic, K. Study on electronic properties of alpha-, beta- and gamma-AlH3-The theoretical approach. Comput. Mater. Sci. 2017, 134, 100-108. [CrossRef]

48. Lan, Z.Q.; Sun, Z.Z.; Ding, Y.C.; Ning, H.; Wei, W.L.; Guo, J. Catalytic action of Y2O3@graphene nanocomposites on the hydrogen-storage properties of Mg-Al alloys. J. Mater. Chem. A 2017, 5, 15200-15207. [CrossRef]

49. Zhong, H.C.; Wang, H.; Ouyang, L.Z. Improving the hydrogen storage properties of $\mathrm{MgH} 2$ by reversibly forming $\mathrm{Mg}-\mathrm{Al}$ solid solution alloys. Int. J. Hydrogen Energy 2014, 39, 3320-3326. [CrossRef] 